\title{
INTEGRATING DESTINATION ATTRIBUTES, POLITICAL (IN)STABILITY, DESTINATION IMAGE, TOURIST SATISFACTION, AND INTENTION TO RECOMMEND: A STUDY OF UAE
}

\author{
Riyad Eid \\ United Arab Emirates University \\ Yasser Ahmed El-Kassrawy \\ Tanta University \\ Gomaa Agag \\ Nottingham Trent University
}

\begin{abstract}
Very limited attention has hitherto been paid to political-specific issues that may significantly guide the successful formation of destination image. Therefore, the purpose of this article is to examine the interrelationships between destination attributes, political (in)stability, destination image, tourist satisfaction, and intention to recommend, to build a conceptual framework of the drivers and outcomes of destination image. Twelve hypotheses (null and alternative) were developed and examined, using a sample of 829 tourists visiting the UAE. Results show that tourists' evaluation of the destination attributes and political (in)stability act as antecedents of perceived destination image. Furthermore, political (in)stability and destination image have a strong effect on tourist satisfaction and intention to recommend. The current study enhances current theorizations by examining the merits of political (in)stability in models of tourists' intention to recommend. From a practical perspective, the study presents significant implications for destination marketers.
\end{abstract}

KEYWORDS: destination image; destination attributes; political (in)stability; tourist satisfaction; intention to recommend; United Arab Emirates

Modeling the antecedents of destination image remains a common research agenda in the tourism literature (Armenski, Dwyer, \& Pavluković, 2018; Eid \& Elbanna, 2018; Gannon et al., 2017; Prayag, Hosany, Muskat, \& Del Chiappa,

\footnotetext{
Authors' Note: The authors sincerely thank the editor, the associate editor, and the anonymous reviewers of the Journal of Hospitality \& Tourism Research for their constructive and valuable comments and suggestions. This work was funded by the UAEU (CBE) Grant G00002374.
} 
2017), tourist satisfaction (Alegre \& Garau, 2010; Assaker \& Hallak, 2013; Dolnicar, Coltman, \& Sharma, 2015), and so does intention to recommend a destination (Alvarez \& Campo, 2014; Chen \& Chen, 2010; Dolnicar et al., 2015). Recently, the Tourism and Travel Research Association (TTRA) built a membership-wide plan of the most urgent problems in tourism studies, examining destination image and competitiveness as one of the top two management research concerns that were critical for decision makers over the next few years (Williams, Stewart, \& Larsen, 2012). However, with all the political risks affecting the world, it is important for the current theorizations to include attitudes to political (in)stability (terror and security risks) and their influence on tourists' intention to recommend a destination as key influential factors in the destination image models. Destination image evaluation is necessary to design an efficient marketing plan and assists the decision makers to show what society tourists are anticipating in order to develop realistic expectations (Eid \& Elbanna, 2018).

However, although previous literature acknowledges the significance of studying the political (in)stability of destinations (Eid \& Elbanna, 2018), previous studies have failed to simultaneously test the interrelationship between destination attributes, political risk attitudes, destination image, satisfaction of consumer, and recommendation willing. The present literature can be split into three groups. The first category of writers (e.g., Armenski et al., 2018; Chen \& Chen, 2010; Chen \& Phou, 2013; Chi \& Qu, 2008; Prayag et al., 2017) theorize destination image as a predictor of tourist satisfaction and/or tourist intentions, but ignore destination attributes in their framework. The second set of researchers (Crouch, 2011; Eid \& El-Gohary, 2015; Eusébio \& Vieira, 2013) theorize the interrelationships between destination attributes, satisfaction, and/or tourist intentions but ignores destination image in their framework. The third set (Elliot, Papadopoulos, \& Kim, 2011; Eusébio \& Vieira, 2013; Hallmann, Zehrer, \& Müller, 2015) theorize the interrelationships between destination attributes, destination image satisfaction, and/or tourist intentions but exclude attitudes the destination's political (in)stability from their conceptualization.

Moreover, study has hitherto concentrated only on the influence attacks of tourists or political conflicts on tourism, while no previous studies have covered political stability and the relationship between such an influential dimension and destination image (Hall, 2010). In an information age, people became more knowledgeable of a destination by their exposure to the information received from TV, newspapers, conversations, or the social media. Such information has a heavy impact on the destination's image. Therefore, information about political (in)stability has great influence on the tourism activity in different destinations (Alvarez \& Campo, 2014; Hall, 2010).

While there have been many studies considering the effect of location attributes, destination image, and tourist satisfaction, among others, on intention to recommend, literature regarding the importance of political stability as a major contributor to intention to recommend is relatively scant (Sannassee \& Seetanah, 2015). Moreover, a series of previous researches discuss the impacts, mostly 
negative, of political instability in terms of safety, security, conflicts, and danger, such as several terrorist attacks that have been recently occurring in different places such as Paris (France) and Manchester (United Kingdom; Eid \& Elbanna, 2018; Walters, Wallin, \& Hartley, 2018). However, very limited studies have discussed the positive impact of the political stability as a vital prerequisite for tourists choosing a destination. Therefore, the present research is an attempt to fill this gab by shedding light on the importance of political stability as a major contributor to destination image and a destination recommendation intention.

To bridge the above gaps, the present study aims to examine the antecedents and consequences of the destination image, to build a framework incorporating destination attributes, attitudes to political (in)stability, destination image, customer satisfaction, and consequences of all these on a destination recommendation intention and to test the proposed hypotheses (null and alternative) based on the study model in a non-Western context.

\section{LITERATURE REVIEW AND HYPOTHESES DEVELOPMENT}

The present study's conceptual framework (Figure 1) has been developed based on the tourism literature and marketing theories. Figure 1 demonstrates the links between the study variables. These relationships consist of two sets of hypotheses:

1. The effect of destination attribute and political (in)stability attitudes on destination image.

2. The effect of destination image and political (in)stability attitudes on both tourist satisfaction and intention to recommend.

The first part of the model shows the different destination attributes that affect the formation of the destination image. These attributes have been classified based on the previous literature into physical and nonphysical attributes (Eid \& Elbanna, 2018). The second part of the figure covers the main contribution of this article as it shows the effect of the political stability on the formation of destination image. Here again, the availing of the destination attributes, coupled with political stability, is an undeniable contributor to improving a destination's image (Sannassee \& Seetanah, 2015). The final stage covers the outputs of our model that include both tourist satisfaction and intention to recommend.

The following part demonstrates a brief justification for each variable, followed by the hypotheses development (null and alternative). The relevant background for the development of hypotheses is shown in the following sections.

\section{The Impact of Political (In)Stability on Tourism Development}

Tourism play a critical role in creating employment chances and income in many societies' particular, developing societies. Due to the nature of tourism industry, it creates many jobs (United Nations World Tourism Organization 


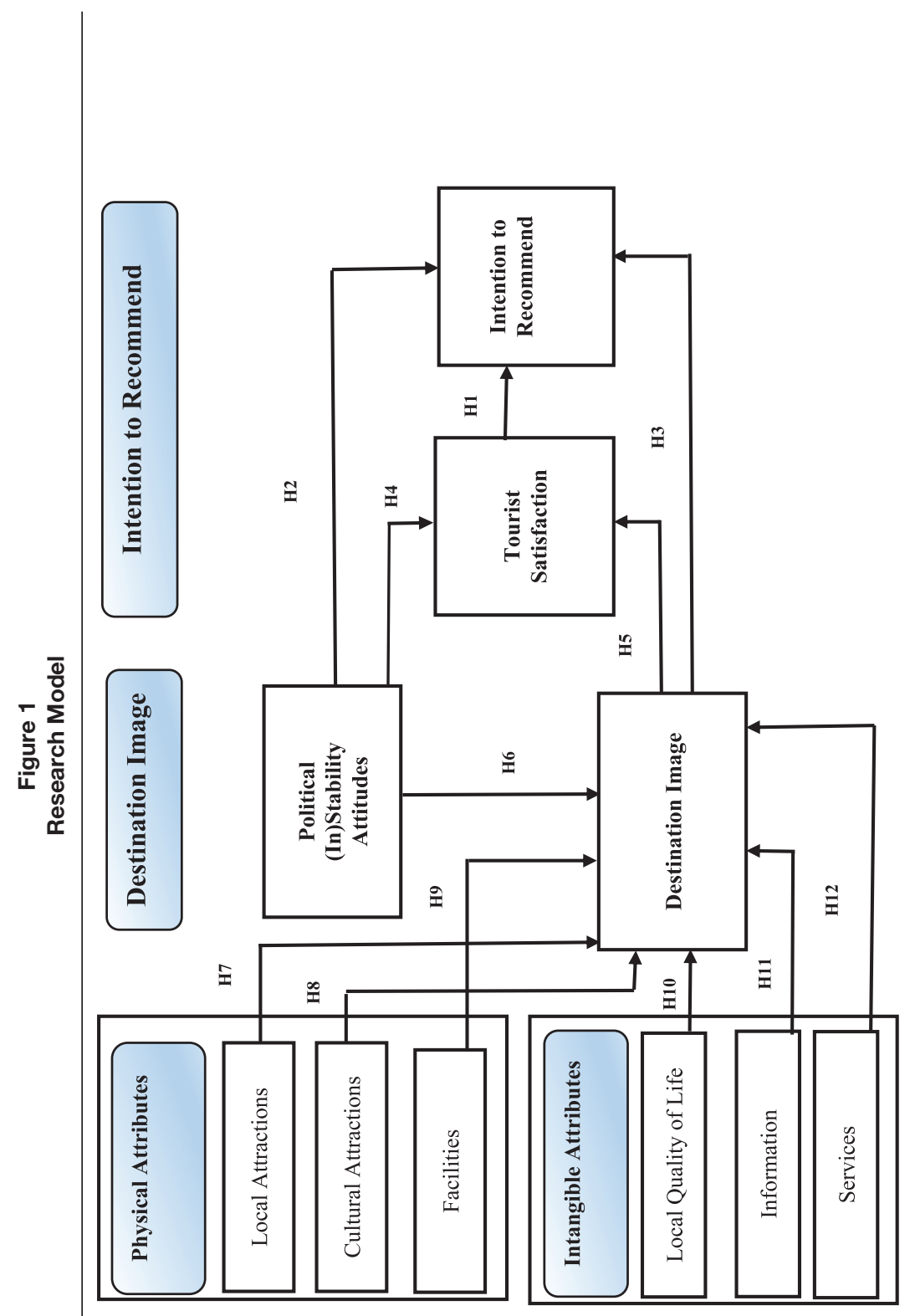


[UNWTO], 2015). For most of the developing societies, tourism plays a significant role to reduce the poverty and provide job opportunities to support the poor people.

Like other business, tourism sector is affected by political environment and situations. For instance, for those countries who have a stable governance and political situation, this will support and encourage foreign and local investments (e.g., hotels, restaurants, and infrastructures) and in services (e.g., marketing ads, foods, and security). These investments in tourism industry will improve the society economic growth as well as improving the country image as a comfortable and safe for tourists. Hall and O'Sullivan (1996) quoted that "issues of political stability and political relations within and between states are extremely important in determining the image of destinations in tourist generating regions and ... the real and perceived safety of tourists" (p. 105). Any society encounters a political issue and terrorist incidence, other countries will warn their people not to visit these countries and this will influence negatively on the other countries tourism sector.

\section{Political Stability and Government Tourism Policy in UAE}

Travelers want to have a positive image of any country destination and feel secure and safe.

Governments play an important role and carrying out pro-tourism rules can assist to guarantee that like conditions. Stable political situations consider an important attribute for people and promote them to recommend this destination. Previous studied pointed out that political stability had a significant effect on intention to visit and recommend (Loi, So, Lo, \& Fong, 2017; Zhang, $\mathrm{Fu}, \mathrm{Cai}, \& \mathrm{Lu}, 2014)$. Furthermore, Chen and Tsai (2007) pointed out that perceived safety and risks improve tourists' intention to recommend and revisit. Moreover, Seetanah, Teeroovengadum, and Nunkoo (2018) have found that political stability is the most important driver of tourists' willing to recommend.

A stable political condition enhances a high demand for tourism activities. This is because, tourists who come to different countries for a period greater than 24 hours always check on particular elements like safety (Goeldner \& Ritchie, 2007). They consider a stable political situation to be peaceful and, therefore, enhance security. This perception makes the tourists take advantage of the safety element. On the other side, a political condition that is unstable does not attract many tourists. This is because tourists always consider such places unsafe. They view these places as not having adequate security. This factor deters tourists from exploiting leisure in such locations. Islamic religion dominates the UAE, but any other religion can be practiced and there is a high level of openness compared with other Middle East countries (Eid \& Elbanna, 2018). The political situation is stable and gets its strength based on the human rights. 


\section{Destination Attributes}

Destination attributes are the group of disparate elements that promote tourists to a destination (Gannon et al., 2017; Kim, 2014). Researchers have identified the destination attributes that configure the image of the destination (Crouch, 2011; Eid \& El-Gohary, 2015; Eusébio \& Vieira, 2013; Gannon et al., 2017; Kim, 2014). For example, Walmsley and Young (1998) identify five types of destination attributes: to do with the economy, the tangible environment, brand impressions, activities and facilities, and people. Eid (2015) defines the Islamic attributes of a destination that are needed to build a good destination image from the Muslim perspective. Finally, Eid and Elbanna (2018) suggest a solid, rigorous, and integrative model of destination attributes that includes two basic dimensions: (1) Physical attributes and (2) Intangible attributes.

\section{Destination Image}

Destination image can refer to tourist mental representation of feeling and knowledge of specific destination (Crompton, 1979; Fakeye \& Crompton, 1991). In the context of marketing, destination image plays a significant role in improving consumers' perceived value, satisfaction, intention, and decision making (e.g., Chen \& Tsai, 2007; Chi \& Qu, 2008; Fu, Ye, \& Xiang, 2016). Prior research pointed out that destination image is a multidimensional variable that consists of both affective and cognitive dimensions (Baloglu \& Brinberg, 1997; Eid \& Elbanna, 2018; Fu et al., 2016; Gartner, 1993; Sweeney \& Soutar, 2001). The former considers destination image as consumers subjective feeling about the destination (Baloglu \& Brinberg, 1997; Fu et al., 2016; Sweeney \& Soutar, 2001), while the latter views destination image as an assessment of a variety of destination attributes (Bigné, Andreu, \& Gnoth, 2005; Gartner, 1993). In the field of destination image, qualitative and quantitative researches have been conducted to confirm that destination image has a significant effect on tourists' intention to recommend and their satisfaction (e.g., Eid \& El-Gohary, 2015; Fu et al., 2016; Hyun \& O’Keefe, 2012).

\section{Political (In)Stability Attitudes}

Matthews (1974), Richter and Waugh (1986), Matthews and Richter (1991), and Roehl and Fesenmaier (1992) have initiated the stream of research on the relationship between political (in)stability and tourism and still continue to inspire tourism research. According to Roehl and Fesenmaier (1992), political (in)stability includes three basic dimensions (physical risk and risk to equipment, vacation risk, and destination risk). Fuchs and Reichel (2006) investigated destination risk perception and identify six destination risk dimensions, one of them being political and safety risk.

Undoubtedly, tourism is affected by the political situation, which goes behind the scope of formal government processes and structure and is therefore a 
hidden and indirect force in much tourism studies (Henderson, 2000). Therefore, the present study examines the definition of political (in)stability and its effects on destination image. Political (in)stability and tourism have been studied from different stakeholder standpoints. For example, travel agents and their influence on destination resilience in the face of instability; tourists and their opinion about politically (in)stable destinations (Cavlek, 2002); public organizations and local governments and their encouragement of tourism activities (Altinay \& Bowen, 2006); and international tourism and economic development and how could it improve different economy sectors (Katircioglu, 2009).

It is evidenced that regardless of the several political variables of tourism, interconnections among political (in)stability and tourism are still insufficiently examined. Prior research asserted that the political variable is a dimension that has a great impact on the destination nature and the tourism industry of the society (Murphy, Pritchard, \& Smith, 2000). In addition, Teye (1988) pointed out that political factors may influence the nature and form of destination competitiveness. Safety anxiety and risk have been identified as strong drivers of not visiting a destination (Sönmez \& Graefe, 1998). It has been found that political instability plays a negative role on tourism demand in both developing and developed societies (Eilat \& Einav, 2004). Similarly, Buda (2016) asserted that political instabilities are viewed to be antithetical with development, planning, and management of viable and prosperous tourism. Finally, according to Walters et al. (2018), tourists' switching or cancellation behaviors because of terrorism attacks had strong economic consequences for the host community and can lead to significant loses to the country's government.

\section{Tourist Satisfaction}

Satisfaction is critical for the successful marketing of destinations, since it is known to significantly affect destination selection, spending, willingness to revisit, and recommend to others (Yoon \& Uysal, 2005). Most of the previous literature (Del Bosque \& San Martín, 2008) used the concept of cognitive satisfaction, explaining consumer satisfaction as a postconsumption assessment that matches or goes beyond their anticipations (Eid, 2015), while some previous tourism studies treat satisfaction as an emotional reaction resulting from the experience of consumption (Eid \& El-Gohary, 2015).

Although the previous literature includes several different meanings of satisfaction, at least two forms of satisfaction are widespread (Ekinci, Dawes, \& Massey, 2008; Nam, Ekinci, \& Whyatt, 2011; Yoon \& Uysal, 2005): one is related to a single transaction (transient satisfaction) while the other is cumulative. Transient satisfaction can be viewed as behaviors and activities that occur where there is a single interaction in a service encounter (Oliver, 1997). Cumulative satisfaction is viewed as one kind of assessment of the last service experience that is nevertheless according to all encounters with the same sellers (Ekinci et al., 2008; Nam et al., 2011). 


\section{Intention to Recommend}

Although expanding the evaluation of the formation of the destination image beyond mere destination attributes represents one of the areas of the tourism field that still lacks systematic investigation (Eid \& Elbanna, 2018), our model also includes a tourist's intention to recommend a destination as a possible way of evaluating the success of a destination image. Recommending a destination to others is a post-visit behavior that is often of significant commercial value to area developers, but has often been ignored by researchers, due to an overwhelming concentration on the visit itself. We may also recognize in today's world that destination image can have more than individual importance, since social networks provide new paths for the powerful dissemination of attitudes and even behaviors. Therefore, as a third key dependent variable, this research includes intention to recommend.

\section{Hypotheses}

\section{Tourists' Intention to Recommend the Destination}

Feelings resulting from consumption experiences make memories that tourists use to configure prior consumption assessments of satisfaction (Westbrook \& Oliver, 1991). Furthermore, tourists are usually influenced by word-of-mouth when judging the quality of any destination (Venkatesh \& Brown, 2001); they are also capable of sharing their own experiences in the discourse. Obviously, the literature determining the link among satisfaction and intention to recommend notes that satisfied tourists are very much the most likely to recommend a destination (Lee, Lee, \& Lee, 2014). Similar results are found by Goldsmith and Flynn (1992), who showed that tourists' high satisfaction can influence the intention to recommend a destination to their social network. Previous studies maintain that reports of political (in)stability will (negatively) positively affect the image of the destination as well as the intention to recommend it (Alvarez \& Campo, 2014). Furthermore, previous research (Hall, Timothy, \& Duval, 2004) has found also that place image affects travelers' behaviors and intentions (e.g., Lee et al., 2014). Finally, Assaker and Hallak (2013) pointed out that satisfaction plays a mediating role in the link among image and intention to recommend. Thus, we proposed the following hypotheses:

Null Hypothesis 1: Tourist satisfaction with a destination has no significant effect on the intention to recommend this destination to others.

Alternative Hypothesis 1: Tourist satisfaction with a destination will positively influence the intention to recommend this destination to others.

Null Hypothesis 2: Political (in)stability of the destination will have no significant influence on the intention to recommend this destination to others.

Alternative Hypothesis 2: Political (in)stability of the destination will (negatively) positively influence the intention to recommend this destination to others. 
Null Hypothesis 3: Destination image will have no significant influence on the intention to recommend this destination to others.

Alternative Hypothesis 3: Destination image will positively influence the intention to recommend this destination to others.

\section{Political (in)Stability Attitude and Tourist Satisfaction}

Marketing-related studies (Eid \& Elbanna, 2018; Ladhari, 2007) and tourism-related studies (Bigné et al., 2005; Del Bosque \& San Martín, 2008; Saha \& Yap, 2014) confirm a relationship between positive events and satisfaction. In tourism, positive emotions such as minimized risk (Alvarez \& Campo, 2014; Saha \& Yap, 2014), joy (Faullant, Matzler, \& Mooradian, 2011), happiness, and pleasure (Grappi \& Montanari, 2011) had an effect on satisfaction. Alvarez and Campo (2014) showed that political (in)stability can generate (dis)satisfaction. This relation has been demonstrated in contexts such as theme parks (Bigné et al., 2005) and services of tourists like restaurant services (Lin \& Mattila, 2010). Therefore, we feel confident in theorizing a causal link between political (in)stability and tourist satisfaction.

Null Hypothesis 4: Political (in)stability of the destination will have no significant influence on the tourist satisfaction.

Alternative Hypothesis 4: Political (in)stability of the destination will influence tourist satisfaction.

\section{Destination Image and Tourist Satisfaction}

Destination image has been reported in reviews to have an important role in effecting several tourist behavior variables, such as destination choice and intention to recommend (Eid, 2015; Eid \& Elbanna, 2018). Gannon et al. (2017) asserted that destination attributes effect destination image. Moreover, image effects posttravel assessments (tourist satisfaction) and future behavior intentions, including recommendations to others (Eid \& El-Gohary, 2015). In general, positive perception of a destination image has been found to positively affect tourist satisfaction (Agag \& El-Masry, 2017; Bigné et al., 2005). Chi and $\mathrm{Qu}$ (2008) found that destination image affects tourist satisfaction, which in turn affects intention to recommend. Thus, the following hypotheses have been developed:

Null Hypothesis 5: Destination image will have no significant influence on the tourist satisfaction.

Alternative Hypothesis 5: Destination image will positively influence tourist satisfaction.

\section{Political (In)Stability Attitude and Destination Image}

Previous literature (Causevic \& Lynch, 2013; Fuchs, Uriely, Reichel, \& Maoz, 2013; Saha \& Yap, 2014) has argued that political (in)stability may 
change the image of a country positively, such as after organizing a successful world event (Olympic Games) or negatively (e.g., the events of September 11th for the United States). Many studies treat tourists as rational and risk-sensitive customers. Therefore, the political risks of going to a specific destination should logically affect tourists' perceptions of the destination image and, thus, influence tourists' visits to it (Blake \& Sinclair, 2003; Roehl \& Fesenmaier, 1992). According to Causevic and Lynch (2013), Neumayer (2004), and Richter (1983), it is importantly impossible to build tourism if potential tourists perceive political instability and perceive this as a threat to their personal safety. Therefore, the following hypotheses have been developed:

Null Hypothesis 6: The political (in)stability of the destination will have no significant influence on the destination image.

Alternative Hypothesis 6: The political (in)stability of the destination will (negatively)positively influence the destination image.

\section{Destination Attributes and Destination Image}

Destination image is influenced by destination attributes (Agag \& El-Masry, 2016a; Eid \& Elbanna, 2018; Walmsley \& Young, 1998). Previous research has shown that consumers feel emotions about physical and intangible attributes (Farber \& Hall, 2007). Undoubtedly, the reports by previous studies can vary on the attributes of destinations that are considered relevant to creating a good destination image (Eid \& Elbanna, 2018; Eusébio \& Vieira, 2013). The selection of the destination attributes included in this study was based on a combination of elements from the literature (e.g., Agag \& El-Masry, 2016b; Alegre \& Garau, 2010; Jeong, Holland, Jun, \& Gibson, 2012; Lee \& Hsu, 2013; Su, Cheng, \& Huang, 2011), with Eid and Elbanna's (2018) classification of destination attributes as either physical or intangible. The destination attributes become experiential elements that form the travelers' destination image (Kim, 2014). Therefore, we propose the following hypotheses:

Null Hypothesis 7: The local attractions of the destination have no significant effect on the destination image.

Alternative Hypothesis 7: The local attractions of the destination have a significant effect on the destination image.

Null Hypothesis 8: The cultural attractions of the destination have no significant effect on the destination image.

Alternative Hypothesis 8: The cultural attractions of the destination have a significant effect on the destination image.

Null Hypothesis 9: The facilities of the destination have no significant effect on the destination image.

Alternative Hypothesis 9: The facilities of the destination have a significant effect on the destination image. 
Null Hypothesis 10: The quality of life of the destination has no significant effect on the destination image.

Alternative Hypothesis 10: The quality of life of the destination has a significant effect on the destination image.

Null Hypothesis 11: Information has no significant effect on the destination image.

Alternative Hypothesis 11: Information has a significant effect on the destination image.

Null Hypothesis 12: Services have no significant effect on the destination image.

Alternative Hypothesis 12: Services have a significant effect on the destination image.

\section{RESEARCH METHODOLOGY}

\section{Data Collection}

The current study population includes tourists above 18 years old. A selfadministered questionnaire method and convenience sampling technique (Saunders, Lewis, \& Thornhill, 2007) have been used when questionnaires are given to international visitors at Varity places in the UAE during the fall of 2016. In total, 1,500 questionnaires were distributed at different UAE attractions including Dubai, Abu Dhabi, Ajman, Sharjah, Fujairah, Ras Al Khaimah, and Umm Al Quwain. In total, 857 participants were approached and 38 with missing values were excluded. Therefore, 829 replies were considered valid for further analysis. The effective response rate was $55.26 \%(829 / 1,500)$. Our sample size meets the recommendation of Eid (2015). Since we have 829 questionnaires and 12 variables, the size of the research sample was suitable for using structural equation modelling (SEM).

Of the 829 respondents who participated in the current study, $52.3 \%$ were men and $47.7 \%$ were women. Most of the participants were aged between 25 and 34 years $(49.0 \%)$ and had a bachelor's degree $(45.7 \%)$. Regarding to the income level, $12.4 \%$ of the participants stated that their monthly household income was less than $\$ 1,000$ per month; for $24.3 \%$, it was between $\$ 1,000$ and $\$ 1,999$; for $22.6 \%$ it was between $\$ 2,000$ and $\$ 2,999$; for $22.2 \%$ it was between $\$ 3,000$ and $\$ 4,999$; and for $18.5 \%$ it was greater than $\$ 5,000$ per month. Finally, the current study data were gathered from 30 different societies: Algeria (1.7\%), Australia (0.9\%), Afghanistan (1.4\%), Bahrain (3.3\%), Bangladesh $(2.3 \%)$, Canada (3.1\%), Colombia (0.7\%), Dominica (0.6\%), Egypt (4.1\%), France $(1.7 \%)$, Germany $(1.2 \%)$, Ghana $(0.8 \%)$, Hungary $(0.6 \%)$, India $(3.2 \%)$, Indonesia (2.7\%), Iran (2.4\%), Iraq (2.8\%), Ireland (1.5\%), Jamaica (0.2\%), Jordan (3.6\%), Kingdom of Saudi Arabia (5.4\%), Kuwait (2.4\%), Lebanon (2.6\%), Libya (1.6\%), Malaysia (2.4\%), Mexico (0.8\%), Morocco (1.8\%), New Zealand (0.9\%), Oman (3.8\%), Pakistan (2.8\%), Palestine (2.7\%), Portugal (0.8\%), Qatar (0.9\%), Romania (1.3\%), Russia (3.4\%), Singapore (0.9\%), Spain (1.1\%), Sudan (2.4\%), Sweden (1.7\%), Syria (3.6\%), Tunisia (2.6\%), Turkey 
(2.8\%), the United Kingdom (4.6\%), Ukraine (1.1\%), the United States (4.2\%), and Yemen (2.6\%).

This study assesses the common method bias in three different approaches (Podsakoff \& Organ, 1986). First, Harmans' single-variable test indicated that the largest factor accounted for $21.39 \%$ (the variances demonstrated ranged from $18.46 \%$ to $21.39 \%$ ) and no single factor accounted for more than $50 \%$ of the variance. Second, the study used the general factor covariate method in order to evaluate method effects. The findings demonstrated that the reestimated framework with the common method variance factor demonstrated insignificant framework enhancement compared with the original one. Third, Lindell and Whitney's (2001) marker variable method was used. All coefficients remained significant after the marker variable has been controlled. Consequently, the results regarding the common method bias confirm that it was not a serious concern.

\section{Research Instrument Development: Measures}

This research, wherever possible, adopted validated scales that had been used before. In conceptualizing the destination attributes, the literature shows that destination attributes include both physical and intangible elements. We followed Eid and Elbanna (2018) in defining them as two second-order constructs that include of six first-order variables altogether. Physical attributes and intangible attributes measured by five, five, four, five, five, and four items, respectively. We borrowed or adapted these items from Gallarza and Saura (2006), Lee and Hsu (2013), Jeong et al. (2012), Sanchez, Callarisa, Rodriguez, and Moliner (2006), and Su et al. (2011). In conceptualizing destination image, we followed $\mathrm{Fu}$ et al. (2016) in defining it as a second-order variable that includes two firstorder variables - cognitive image and affective image - assessed by four and four items, respectively. We used these measures from Bigné et al. (2005), Fu et al. (2016), and Sweeney and Soutar (2001).

The original Fuchs et al. (2013) scale of political (in)stability is used in this study. In spite of the fact that this scale was designed to assess instability, we modified the original to assess the degree of stability of the destination. Thus, political (in)stability was measured by four items adapted from Fuchs et al. (2013). In measuring consumer satisfaction, the present study used prior measures from Alegre and Garau (2010), Chen and Chen (2010), and Gallarza and Saura (2006). Finally, intention to recommend was conceptualized using four items adopted from the original scale developed by Prayag et al. (2017).

\section{DATA ANALYSIS AND RESULTS}

To assess the study conceptual model's nomological validity, the present study analyzed the survey data using SPSS and AMOS 23 software with a twostep analytic phase (Anderson \& Gerbing, 1988). First, the measurement model was assessed to evaluate the reliability and validity of the study measures. 
Table 1

Reliability Analysis

\begin{tabular}{lcccc}
\hline Constructs & N of Items & Mean & $S D$ & Reliability \\
\hline Local Attractions (LA) & 5 & 3.78 & 0.903 & 0.873 \\
Cultural Attractions (CA) & 5 & 3.666 & 0.812 & 0.860 \\
Facilities (F) & 4 & 3.788 & 0.941 & 0.851 \\
Local Quality of Life (LQL) & 4 & 3.559 & 0.861 & 0.871 \\
Information (I) & 4 & 3.622 & 0.902 & 0.850 \\
Services (S) & 4 & 3.630 & 0.930 & 0.855 \\
Political (in)stability (PS) & 8 & 3.380 & 1.035 & 0.948 \\
Destination Image (DI) & 4 & 3.481 & 1.083 & 0.956 \\
Tourist Satisfaction (TS) & 4 & 3.816 & 0.888 & 0.927 \\
Intention to Recommend (ITR) & 4 & 3.847 & 0.914 & 0.883 \\
\hline
\end{tabular}

Second, the structural model was established to evaluate goodness of fit of the model and hypothesis testing (Hair, Hult, Ringle, \& Sarstedt, 2016).

First, the present study used Cronbach's alpha reliability coefficient and items-to-total correlation to assess the psychometrical properties of our constructs (Anderson \& Gerbing, 1988). This method leads to the exclusion of two items from the local quality of life scale and of one item from the available information scale, the inclusion of which decreased the value of the reliability coefficients. As can be seen in Table 1, all the scales have reliability coefficients ranging from 0.850 to 0.956 , which all exceed the cutoff level of 0.65 set for basic research (Bagozzi, 1994).

The present study evaluated the normality test using the skewness and kurtosis of each item (Eid, 2015). Before conducting the measurement model, an exploratory factor analysis was conducted using SPSS to recognize the underlying variables (Anderson \& Gerbing, 1988). We conducted principal component analysis in order to extract a set of variables. All the 47 items were found with their communalities greater than 0.50 . A Bartlett test of sphericity (4158.348) and KMO measure (0.959) of sampling adequacy confirmed a significant association between the factors to warrant the factor analysis application (Hair et al., 2016).

\section{Measurement Model}

To assess the measurement model, both reliability and validity must be satisfactory (Hair et al., 2016). All items had significant influence on their specified variables $(p<.001)$, and loaded above 0.60 on their constructs (Hair et al., 2016). The findings of the current study provided evidence for each scale unidimensionally (Table 2). The internal consistency of each variable was supported as composite reliability, Cronbach's alphas of study constructs gave results above 0.70 , exceeding the recommended value proposed by 
Table 2

Scale Items, Factor Loadings, and Sources

\begin{tabular}{|c|c|c|}
\hline Construct/ltems & Factor Loading & Source \\
\hline \multicolumn{3}{|l|}{$\begin{array}{l}\text { Local Attractions (LA): [variance extracted: } \\
7.83 \% \text { ] } 2\end{array}$} \\
\hline $\begin{array}{l}\text { The UAE has many interesting attractions } \\
\text { to visit. }\end{array}$ & .731 & \multirow{5}{*}{$\begin{array}{l}\text { Adopted from Eid } \\
\text { and Elbanna } \\
\text { (2018) and } \\
\text { Gallarza and Saura } \\
(2006)\end{array}$} \\
\hline $\begin{array}{l}\text { The UAE is a different and fascinating } \\
\text { destination to visit. }\end{array}$ & .765 & \\
\hline The UAE has plenty of quality hotels. & .697 & \\
\hline $\begin{array}{l}\text { The UAE is a restful and relaxing } \\
\text { destination to visit. }\end{array}$ & .732 & \\
\hline $\begin{array}{l}\text { The UAE has important museums and art } \\
\text { galleries. }\end{array}$ & 682 & \\
\hline \multicolumn{3}{|l|}{$\begin{array}{l}\text { Cultural Attractions (CA): [variance } \\
\text { extracted: } 4.96 \%] 3\end{array}$} \\
\hline The UAE has many natural attractions. & .636 & \multirow{5}{*}{$\begin{array}{l}\text { Adopted from Eid } \\
\text { and Elbanna } \\
\text { (2018) and Lee } \\
\text { and Hsu (2013) }\end{array}$} \\
\hline $\begin{array}{l}\text { The UAE offers a wide variety of outdoor } \\
\text { activities. }\end{array}$ & .716 & \\
\hline $\begin{array}{l}\text { The UAE Good tourist information is } \\
\text { readily available. }\end{array}$ & .648 & \\
\hline $\begin{array}{l}\text { The UAE has many cultural and historical } \\
\text { attractions. }\end{array}$ & .721 & \\
\hline The UAE has unique architectural styles. & .664 & \\
\hline \multicolumn{3}{|l|}{ Facilities (F): [variance extracted: $4.91 \%$ ] 4} \\
\hline The UAE has well-appointed facilities. & .657 & \multirow{4}{*}{$\begin{array}{l}\text { Adopted from Eid } \\
\text { and Elbanna } \\
\text { (2018) and Jeong } \\
\text { et al. (2012) }\end{array}$} \\
\hline Signs and directions are clear in the UAE. & .740 & \\
\hline $\begin{array}{l}\text { Accessibility for those with disabilities is } \\
\text { perfect in the UAE. }\end{array}$ & .782 & \\
\hline $\begin{array}{l}\text { Recreation activities in the UAE are highly } \\
\text { compatible. }\end{array}$ & .685 & \\
\hline \multicolumn{3}{|l|}{$\begin{array}{l}\text { Local Quality of Life (LQL): [variance } \\
\quad \text { extracted: } 2.64 \% \text { ] } 7\end{array}$} \\
\hline $\begin{array}{l}\text { The UAE's standards of cleanliness are } \\
\text { high. }\end{array}$ & 670 & \multirow{4}{*}{$\begin{array}{l}\text { Adopted from Eid } \\
\text { and Elbanna } \\
\text { (2018) and } \\
\text { Sanchez et al. } \\
(2006)\end{array}$} \\
\hline The UAE has a high standard of living. & .772 & \\
\hline Shopping facilities are good in the UAE. & .695 & \\
\hline The UAE is technologically advanced. & .694 & \\
\hline \multicolumn{3}{|l|}{ Information (I): [variance extracted: $2.38 \%$ ] 8} \\
\hline $\begin{array}{l}\text { Traffic information (including } \\
\text { transportation) is easy in the UAE. }\end{array}$ & .718 & \multirow{4}{*}{$\begin{array}{l}\text { Adopted from Eid } \\
\text { and Elbanna } \\
\text { (2018) and Su et } \\
\text { al. (2011) }\end{array}$} \\
\hline $\begin{array}{l}\text { It is easy to obtain information about the } \\
\text { climate in the UAE. }\end{array}$ & .736 & \\
\hline $\begin{array}{l}\text { Current and accurate information is } \\
\text { available in the UAE. }\end{array}$ & .724 & \\
\hline $\begin{array}{l}\text { General information about the UAE is } \\
\text { easy to obtain. }\end{array}$ & .628 & \\
\hline
\end{tabular}


Table 2 (continued)

\begin{tabular}{|c|c|c|}
\hline Construct/Items & Factor Loading & Source \\
\hline \multicolumn{3}{|l|}{ Services (S): [variance extracted: $2.23 \%] 9$} \\
\hline $\begin{array}{l}\text { Tourism employees in the UAE have } \\
\text { sufficient knowledge and skills. }\end{array}$ & .641 & \multirow{5}{*}{$\begin{array}{l}\text { Adopted from Eid } \\
\text { and Elbanna } \\
\text { (2018) }\end{array}$} \\
\hline $\begin{array}{l}\text { Tourism employees in the UAE } \\
\text { understand my needs. }\end{array}$ & .713 & \\
\hline $\begin{array}{l}\text { Tourism employees in the UAE are } \\
\text { courteous and friendly. }\end{array}$ & .746 & \\
\hline $\begin{array}{l}\text { Tourism employees in the UAE handle my } \\
\text { questions efficiently. }\end{array}$ & .771 & \\
\hline \multicolumn{2}{|l|}{$\begin{array}{l}\text { Political (In)Stability (PS): [variance } \\
\text { extracted: } 3.21 \%] 5\end{array}$} & \\
\hline $\begin{array}{l}\text { My family will not worry about my safety } \\
\text { during my stay in the UAE. }\end{array}$ & .646 & \multirow[t]{5}{*}{$\begin{array}{l}\text { Adopted from Fuchs } \\
\text { et al. (2013) }\end{array}$} \\
\hline $\begin{array}{l}\text { Whoever is with me will never be injured } \\
\text { by terror attacks in the UAE. }\end{array}$ & .686 & \\
\hline $\begin{array}{l}\text { I do not fear the effect that political events } \\
\text { around the world might have on the } \\
\text { attitude of the locals toward me. }\end{array}$ & .708 & \\
\hline $\begin{array}{l}\text { My conduct will never be seen in a } \\
\text { negative manner by the locals. }\end{array}$ & .691 & \\
\hline \multicolumn{2}{|l|}{$\begin{array}{l}\text { Destination Image (DI): [variance extracted: } \\
\quad 41.55 \% \text { ] } 1\end{array}$} & \\
\hline $\begin{array}{l}\text { The UAE has Beautiful Scenery/Natural } \\
\text { Attractions. }\end{array}$ & .802 & \multirow{9}{*}{$\begin{array}{l}\text { Adopted from Bigne } \\
\text { et al. (2005), Fu et } \\
\text { al. (2016) }\end{array}$} \\
\hline $\begin{array}{l}\text { The UAE has Interesting Cultural/ } \\
\text { Historical Attractions. }\end{array}$ & .825 & \\
\hline $\begin{array}{l}\text { The UAE has Interesting and Friendly } \\
\text { People. }\end{array}$ & .838 & \\
\hline $\begin{array}{l}\text { The UAE has Unpolluted/Unspoiled } \\
\text { Environment. }\end{array}$ & .796 & \\
\hline The UAE attractions are pleasant. & .801 & \\
\hline The UAE attractions are relaxing. & .777 & \\
\hline The UAE attractions are Exciting. & .754 & \\
\hline The UAE attractions are arousing. & .748 & \\
\hline \multicolumn{2}{|l|}{$\begin{array}{l}\text { Tourist Satisfaction (TS): [variance } \\
\text { extracted: } 2.83 \% \text { ] } 6\end{array}$} & \\
\hline $\begin{array}{l}\text { My decision to visit the UAE was a wise } \\
\text { one. }\end{array}$ & .690 & \multirow{4}{*}{$\begin{array}{l}\text { Adopted from } \\
\text { Alegre and Garau } \\
\text { (2010), Chen and } \\
\text { Chen (2010) }\end{array}$} \\
\hline $\begin{array}{l}\text { I did the right thing when I visited the } \\
\text { UAE. }\end{array}$ & .716 & \\
\hline This experience is exactly what I needed. & .739 & \\
\hline $\begin{array}{l}\text { I feel good about my decision to visit the } \\
\text { UAE. }\end{array}$ & .708 & \\
\hline
\end{tabular}


Table 2 (continued)

\begin{tabular}{|c|c|c|}
\hline Construct//tems & Factor Loading & Source \\
\hline \multicolumn{3}{|l|}{$\begin{array}{l}\text { Intention to Recommend (ITR): [variance } \\
\text { extracted: } 4.91 \%] 4\end{array}$} \\
\hline I will recommend the UAE to other people & .731 & Adopted from \\
\hline $\begin{array}{l}\text { I will say positive things about the UAE to } \\
\text { other people }\end{array}$ & .603 & $\begin{array}{l}\text { Prayag et al. } \\
(2017)\end{array}$ \\
\hline $\begin{array}{l}\text { I will recommend Al-Ain to others as a } \\
\text { favorable destination }\end{array}$ & .772 & \\
\hline $\begin{array}{l}\text { I will encourage friends and relatives to } \\
\text { visit the UAE }\end{array}$ & .672 & \\
\hline
\end{tabular}

Table 3

Measurement Model Results: Confirmatory Factor Analysis

\begin{tabular}{|c|c|c|c|c|c|c|c|c|c|c|}
\hline \multicolumn{11}{|c|}{ Correlations } \\
\hline & LA & $\mathrm{CA}$ & $\mathrm{F}$ & LQL & I & $S$ & PS & DI & TS & ITR \\
\hline LA & 0.760 & & & & & & & & & \\
\hline $\mathrm{CA}$ & $.125^{\star \star}$ & 0.742 & & & & & & & & \\
\hline $\mathrm{F}$ & $.122^{\star \star}$ & $.280^{\star \star}$ & 0.768 & & & & & & & \\
\hline LQL & $.137^{\star \star}$ & $.369^{* *}$ & $.264^{* \star}$ & 0.792 & & & & & & \\
\hline I & $.180^{\star \star}$ & $.370^{* *}$ & $.219^{\star \star}$ & $.362^{\star *}$ & 0.766 & & & & & \\
\hline$S$ & $.172^{\star \star}$ & $.265^{\star *}$ & $.284^{\star \star}$ & $.276^{\star *}$ & $.240^{\star *}$ & 0.772 & & & & \\
\hline PS & $.471^{\star \star}$ & $.198^{\star *}$ & $.205^{\star \star}$ & $.214^{*}$ & $.183^{\star \star}$ & $.270^{\star \star}$ & 0.905 & & & \\
\hline $\mathrm{DI}$ & $.589^{\star \star}$ & $.193^{\star \star}$ & $.202^{\star \star}$ & $.219^{\star \star}$ & $.228^{\star \star}$ & $.264^{\star \star}$ & $.549^{\star *}$ & 0.852 & & \\
\hline TS & $.233^{\star \star}$ & $.215^{\star \star}$ & $.246^{\star \star}$ & $.289^{\star *}$ & $.243^{\star \star}$ & $.260^{\star \star}$ & $.360^{\star *}$ & $.357^{\star \star}$ & 0.872 & \\
\hline ITR & $.184^{\star *}$ & $.198^{\star \star}$ & $.237^{\star \star}$ & $.216^{\star \star}$ & $.207^{\star \star}$ & $.214^{\star \star}$ & $.332^{\star *}$ & $.340^{\star *}$ & $.506^{\star *}$ & 0.809 \\
\hline Alpha & .873 & .860 & .851 & .871 & .850 & .855 & .948 & .956 & .927 & .883 \\
\hline
\end{tabular}

Note: The diagonals represent the average variance extracted and the lower cells represent the squared correlations among the constructs.

${ }^{* *}$ Correlation is significant at the .01 level (2-tailed); ns = correlation is insignificant.

Bagozzi and Yi (1988) and Hair et al. (2016; see Table 2). The value of average variance extracted for each construct ranged from 0.580 to 0.741 , exceeding the recommended value of 0.50 suggested by Fornell and Larcker (1981) and Hair et al. (2016). Therefore, convergent validity was supported. The BentlerBonnet coefficient for our model is 0.927 , which is indicative of adequate convergent validity. Moreover, the average variance extracted square root for all variables was higher than its correlation with any other factor, which supports the discriminant validity of the research variables (Eid \& El-Gohary, 2015; Table 3). In addition, building on Bagozzi (1994), we addressed the multicollinearity issue in our data sets. All the variance inflation factors for the 
variables were below 2, suggesting that collinearity issues were absent from the measurement model.

\section{Structural Model}

As noted above, testing the hypotheses or the structure model evaluation was taken as the second step in assessing our proposed model after assessing the measurement model. The present study model assigns $70 \%$ to destination image, $41 \%$ to tourists' satisfaction, and $55 \%$ to intentions to recommend, which indicates that it has a stronger prediction capacity. The results of testing hypotheses using AMOS-SEM approach are illustrated in Figure 2. The values of the confirmatory factory analysis with maximum-likelihood estimation method demonstrate the satisfactory fit of this model to the data $\left(\chi^{2}=1562.334, d f=602, p<\right.$ $.001, \chi^{2} / d f=2.219$, goodness-of-fit index $[\mathrm{GFI}]=.992$, adjusted goodness-offit index $[\mathrm{AGFI}]=.940$, comparative fit index $[\mathrm{CFI}]=.995$, normed fit index $[\mathrm{NFI}]=.965$, root mean square error of approximation $[\mathrm{RMSEA}]=.066$ ) indicate that our model fit was suitable.

The chi-square test was not statistically significant, which confirmed a good fit. The other fit indicators, along with the squared multiple correlations, reflect a good overall fit with the data (GFI $=.992, \mathrm{AGFI}=.940, \mathrm{CFI}=.995, \mathrm{NFI}=$ .965 , RMSEA $=.066$ ). As noted above, testing the hypotheses or the structure model evaluation was taken as the second step in assessing our proposed model after assessing the measurement model.

The causal effects of political (in)stability and destination image on a tourist's intention to recommend may be indirect or direct effect (i.e., mediated via the effect of tourist satisfaction), or both; in this case, the total effect has been calculated. Table 4 demonstrates the indirect, direct, and total effects of the proposed variables.

To test the 12 null hypotheses, a structural model was used. Most of the hypotheses have been supported. Table 5 demonstrates the estimated path coefficient for each variable. First, apart from the null hypothesis of the cultural attractions $(\beta=0.015, p>.10)$ that has been accepted, Null Hypotheses 6,7 , $9,10,11$ and 12 were not supported, and they were rejected. The alternative hypotheses were accepted. Therefore, the suggested factor positively affects the destination image, namely, local attractions $(\beta=0.460, p<.01)$, Facilities $(\beta=0.047, p<.05)$, local quality of life $(\beta=0.049, p<0.10)$, information $(\beta=0.050, p<.05)$, services $(\beta=0.078, p<.01)$, and political (in)stability $(\beta=0.313, p<.01)$.

Second, tourist satisfaction is significantly influenced by the specified factors, namely, political (in)stability $(\beta=0.424, p>.01)$ and destination image $(\beta=0.237, p<.01)$. Thus, Null Hypotheses 4 and 5 were rejected and Alternative Hypotheses 4 and 5 were accepted.

Finally, the following suggested factors positively affect the tourist intention to recommend, namely, tourist satisfaction (standardized estimate $=0.552$, 


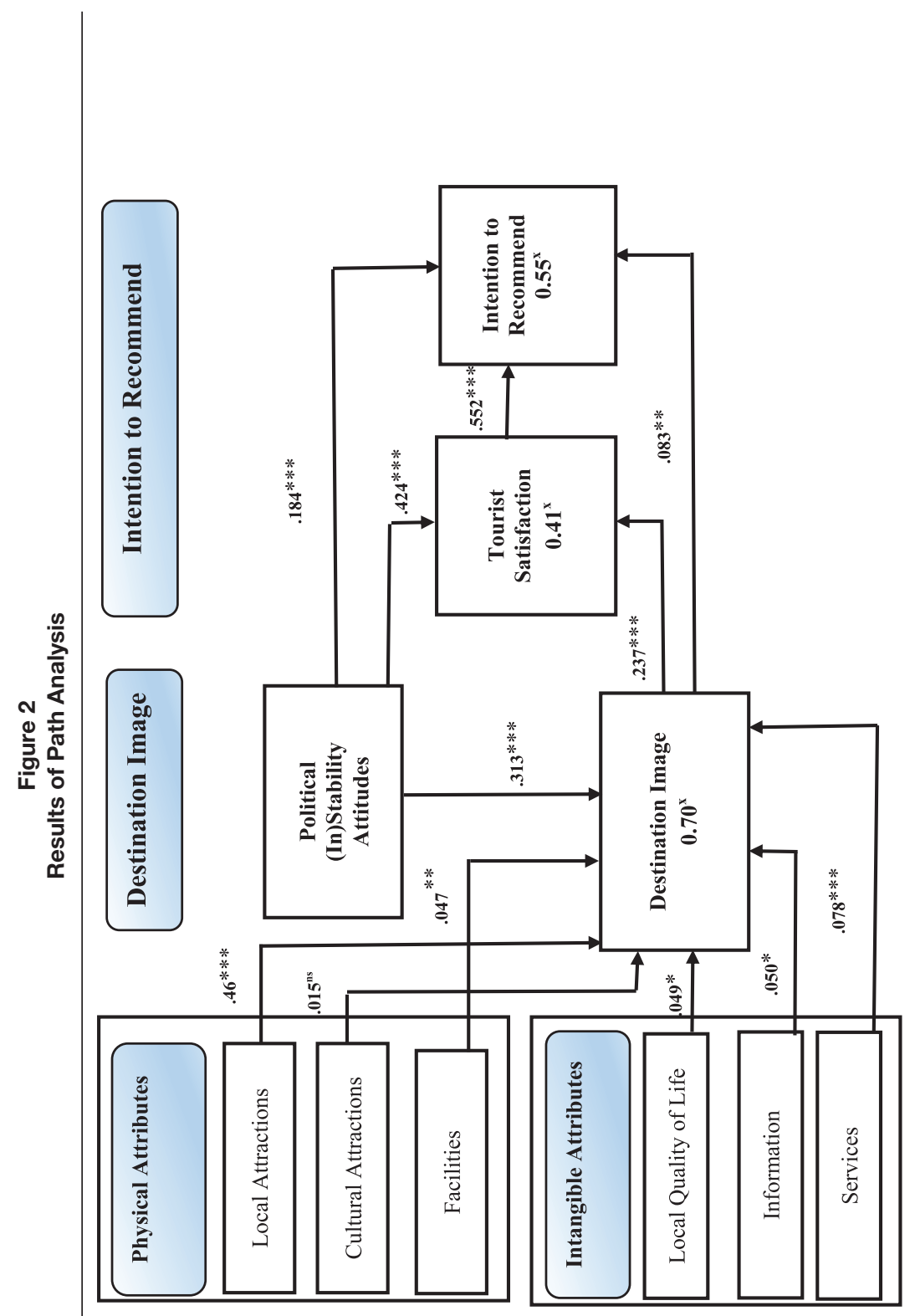


Table 4

Direct, Indirect, and Total Effect

\begin{tabular}{llccc}
\hline Criterion Variable & \multicolumn{1}{c}{ Predictor Variables } & $\begin{array}{c}\text { Direct } \\
\text { Effect }\end{array}$ & $\begin{array}{c}\text { Indirect } \\
\text { Effect }\end{array}$ & $\begin{array}{c}\text { Total } \\
\text { Effect }\end{array}$ \\
\hline $\begin{array}{llcc}\text { Destination } \\
\text { Image }\end{array}$ & Local Attractions (LA) & 0.460 & 0.00 & 0.460 \\
& Cultural Attractions (CA) & 0.015 & 0.00 & 0.015 \\
& Facilities (F) & 0.047 & 0.00 & 0.047 \\
& Local Quality of Life (LQL) & 0.049 & 0.00 & 0.049 \\
& Information (I) & 0.050 & 0.00 & 0.050 \\
Tourist & Services (S) & 0.078 & 0.00 & 0.078 \\
satisfaction & Political (in)stability (PS) & 0.313 & 0.00 & 0.313 \\
Intention to & Political (In)Stability & 0.424 & 0.074 & 0.498 \\
Recommend & Destination Image & 0.237 & 0.000 & 0.234 \\
& Tourist satisfaction & 0.552 & 0.000 & 0.552 \\
& Political (In)Stability & 0.184 & 0.301 & 0.485 \\
& Destination Image & 0.083 & 0.131 & 0.214 \\
\hline
\end{tabular}

Table 5

Standardized Regression Weights

\begin{tabular}{|c|c|c|c|c|}
\hline Predictor Variables & Criterion Variables & $\begin{array}{l}\text { Hypothesized } \\
\text { Relationship }\end{array}$ & $\begin{array}{c}\text { Standardized } \\
\text { Coefficient }\end{array}$ & $R^{2 \mathrm{a}}$ \\
\hline Local Attractions (LA) & Destination Image & $\mathrm{H} 7$ & $0.460^{\star \star \star}$ & 0.699 \\
\hline Cultural Attractions (CA) & Destination Image & $\mathrm{H} 8$ & $0.015^{\mathrm{ns}}$ & \\
\hline Facilities (F) & Destination Image & $\mathrm{H} 9$ & $0.047^{\star *}$ & \\
\hline Local Quality of Life (LQL) & Destination Image & $\mathrm{H} 10$ & $0.049^{*}$ & \\
\hline Information (I) & Destination Image & $\mathrm{H} 11$ & $0.050^{\star \star}$ & \\
\hline Services (S) & Destination Image & $\mathrm{H} 12$ & $0.078^{\star \star \star}$ & \\
\hline Political (in)stability (PS) & Destination Image & $\mathrm{H} 6$ & $0.313^{\star \star *}$ & \\
\hline Political (In)Stability & Tourist satisfaction & $\mathrm{H} 4$ & $0.424^{\star * *}$ & 0.407 \\
\hline Destination Image & Tourist Satisfaction & H5 & $0.237^{\star \star *}$ & \\
\hline Tourist satisfaction & $\begin{array}{l}\text { Intention to } \\
\text { Recommend }\end{array}$ & $\mathrm{H} 1$ & $0.552^{* * *}$ & 0.545 \\
\hline Political (In)Stability & $\begin{array}{l}\text { Intention to } \\
\text { Recommend }\end{array}$ & $\mathrm{H} 2$ & $0.184^{\star \star *}$ & \\
\hline Destination Image & $\begin{array}{l}\text { Intention to } \\
\text { Recommend }\end{array}$ & $\mathrm{H} 3$ & $0.083^{* *}$ & \\
\hline \multicolumn{3}{|l|}{ Statistic } & Suggested & Obtained \\
\hline \multicolumn{3}{|l|}{ Chi-square significance } & $\geq 0.05$ & 0.12 \\
\hline \multicolumn{3}{|l|}{ Goodness-of-fit index (GFI) } & $\geq 0.90$ & 0.947 \\
\hline \multicolumn{3}{|c|}{ Adjusted goodness-of- fit index (AGFI) } & $\geq 0.80$ & 0.839 \\
\hline \multicolumn{3}{|l|}{ Comparative fit index (CFI) } & $\geq 0.90$ & 0.972 \\
\hline \multicolumn{3}{|c|}{ Root Mean Square Residual (RMR) } & $\leq 0.08$ & 0.071 \\
\hline
\end{tabular}

${ }^{*} p<.10 .{ }^{* *} p<.05 .{ }^{* *} p<.01$. ns is not significant 
$p>.01$ ), political (in)stability (standardized estimate $=0.184, p<.05$ ), and destination image (standardized estimate $=0.083, p<.01$ ). Therefore, Null Hypotheses 1, 2, and 3 were rejected and Alternative Hypotheses 1, 2, and 3 were accepted.

Moreover, effect sizes $\left(f_{2}\right)$ were used to evaluate the extent to which the predictor latent variables affect the dependent variable. We used the Cohen (1988) effect size $f_{2}$ to investigate the essential impact of the conceptual framework, which refers to "the degree to which the phenomenon is present in the population." The values of $0.02,0.15$, and 0.35 refer to small, medium, and large effect sizes, respectively, as presented by Cohen (1988). Regarding our proposed model, destination image $\left(f_{2}=0.62\right)$ and intention to recommend $\left(f_{2}=0.49\right)$ have a large effect size, while tourist satisfaction $\left(f_{2}=0.31\right)$ has a medium effect size. Based on Stone-Geisser $Q_{2}$, we tested our structural model predictive validity. The cross-validated construct redundancy $Q_{2}$ is required to test the predictive validity, as the structural model has a predictive validity if the $Q_{2}$ greater than zero (Roldán \& Sánchez-Franco, 2012). The values of $Q_{2}$ in our model are 0.68 for destination image, 0.40 for tourist satisfaction, and 0.53 for intention to recommend, which indicates the strong predictive validity of our model.

\section{DISCUSSION AND IMPLICATIONS}

The present study aims to provide practical and useful directions for tourism organizations and governments seeking to improve their tourism success by investigating the interrelationships between destination attributes, attitudes to political (in)stability, destination image, customer satisfaction, and tourist intention to recommend. Furthermore, it aims to strengthen our understanding of the indirect influence of tourist satisfaction on the link among political stability and destination image, on one side, and tourist intention to recommend a destination, on the other.

The current research contributes to the tourism literature by clarifying image formation. Not only does the current study offer an empirical evaluation of the important components of destination attributes that might affect the successful creation of a favorable destination image, but it also includes political (in)stability as an important factor. In today's turbulent world, with terrorist attacks affecting a number of European countries such as the United Kingdom, France, Germany, and Belgium; Middle Eastern countries such as Egypt, Iraq, Syria, Libya, and Saudi Arabia; and the United States, more attention should be paid to the terror threats or fears relevant to tourists.

Furthermore, the study shows the predictive power of political (in)stability and destination image in the context of tourism. Specifically, the suggested model makes it possible to determine the links among (a) specific destination attributes and destination image; (b) political (in)stability and destination image; (c) political (in)stability, destination image, and tourist satisfaction; and (d) political (in)stability, destination image, traveler satisfaction, and 
willingness to recommend. The findings asserted that political (in)stability and destination image are significant drivers of both tourist satisfaction and intention to recommend.

The findings support prior research (Alegre \& Garau, 2010; Crouch, 2011; Gannon et al., 2017; Kim, 2014) that the actual on-site experience of the destination attributes, in particular, will affect the destination image. For example, Prayag et al. (2017) found that the perceived view of destination-led attributes, such as local attractions, facilities, cultural attractions, and the general ambiance, serve to "pull" tourists about determined destinations. However, the nonsignificant path cultural attraction-destination image (Null Hypothesis 8) is inconsistent with the studies of tourism by Eid and Elbanna (2018) and Lee and Hsu (2013). These differences, however, can be explained in different ways. First, the research contexts are different. Second, they may be justifiable if we recall that tourists look on the UAE more as a place of modern attractions than a cultural and historical destination.

Furthermore, the link between political (in)stability and destination image is also congruent with prior research (Blake \& Sinclair, 2003; Richter, 1983; Roehl $\&$ Fesenmaier, 1992) that asserted a positive and significant link among attitudes to political (in)stability in a destination and the destination image. The results also support prior studies (Blake \& Sinclair, 2003; Roehl \& Fesenmaier, 1992) that identify a positive relationship between political stability (and, conversely, political instability), satisfaction, and eventually willingness to recommend. Furthermore, the results suggest that political stability is more important than destination image in predicting both tourist satisfaction and the intention to recommend. This supports the results of Causevic and Lynch (2013) and Altinay and Bowen (2006) that it is impossible to build tourism if prospects tourists view political instability and interpret it as a threat to their personal security.

Consistent with prior studies (e.g., Prayag et al., 2017), the study asserted the link between destination image and satisfaction. Furthermore, the results support prior studies (Chi \& Qu, 2008) that identify a direct link between destination image and intention to recommend. In particular, destination image has direct and indirect influence on tourist intention to recommend. We were surprised, however, to find that destination image shows only a negligible impact on the intention to recommend. Based on the current study results, a negligible direct influence (0.083) is improved by the indirect positive effect $(0.131)$ of the destination image on the intention to recommend that is mediated via tourist satisfaction levels. Similarly, as proposed in this study, satisfaction had a significant positive effect on intention to recommend. Previous research (Prayag et al., 2017) maintains that satisfied tourists are most likely to report good things about the place to others.

Undoubtedly, the present study results hold considerable implications for destination tourism marketers. The destination image perceived by tourists is critical because it helps them when they next make a travel decision and when they recommend a destination to prospective tourists. Moreover, based on the current study findings, tourists' perceived destination image will affect their 
satisfaction levels, which in turn influence their willingness to recommend the destination. Consequently, those responsible for the country's marketing strategies should put great effort into ensuring that travelers are as well-satisfied as possible. Managers should offer high-level value for tourists through well-prepared and controlled facilities, information; and services, and it should be the priority. These attributes contribute to the destination image.

Prior research found that there is a scarcity on examining the direct link between political (in)stability and destination image. Therefore, the current study findings show that political (in)stability has the greatest role in forming the destination image. This is in line with Eid and Elbanna's view (2018) that the main pillars in the UAE's attractiveness are its security and safety. Danger and conflict are seemingly ousted; security, safety, and stability play a critical role in the UAE tourism industry. The country is perceived by most tourists as a safe place that is protected from the political conflicts in the region. Therefore, the political stability dimension of the country's image is the one that the UAE should concentrate on. Tourism marketers, therefore, should know that one important solution to improving a country's image rate may be to concentrate on highlighting its positive political stability.

United Arab Emirates (33.9\%) led the region's international tourism receipts making tourism revenue of US\$19,496 million, with the highest share across the region. United Arab Emirates, the subregion's top destination, enjoyed double digit growth $(27.8 \%)$ in international arrivals in 2016, thanks to the political stability of the country (UNWTO, 2017). Therefore, the significance of the political stability element about promoting the element of safety were shown. Marketers should know that the improvement in tourist arrival rates was caused by the government philosophy to recommend UAE as a secure destination and the resulting intensive promotional campaign conducted by the UAE ministry of tourism in many societies, such as the United States, Europe, China, and Russia.

The policy implication of this research suggests that governments, which depend extensively on industry of tourism, should preserve their political stability if they want to gain the usefulness of revenue from tourism. The present research supports the theoretical view of Alvarez and Campo (2014) that destination image models should include political stability variables. Then countries which experienced terrorism and political instability would have more accurate expectations of visitors and revenue. It is important to mention that assessing the relationship between destination image, political instability, and intention to recommend is critical, given the significance that policy makers are giving to this industry growth.

\section{LIMITATIONS AND SUGGESTIONS FOR FUTURE RESEARCH}

Though the present study contributes to the literature, it also has some limitations, which provide a direction for further research. First, this study focused on a specific country (UAE) that is classified as a politically stable country that is free of terrorist attacks. Second, we assessed the political stability construct 
using only four items while there is evidence that political stability is a wider construct that should include safety and security (Sannassee \& Seetanah, 2015), probability of terrorism, crime rates, transportation safety (Sönmez \& Graefe, 1998), and conflict (Buda, 2016). Finally, the cross-cultural issue was overlooked in our study, so further studies in different countries might add to the knowledge if our proposed model was validated there.

The present study provides future researchers with some directions on understanding of the relationship between destination attributes, political stability, destination image, tourist satisfaction, and intention to recommend in other stable and nonstable countries. For example, the political stability construct investigated in the current research warrants more in depth study to cover the different issues that reflect it, such as safety, security, probability of terrorism, crime rates, transportation safety, and conflict. Given the importance associated with the political stability in the tourism sector, an interesting idea is to build the quantification of the political stability variable into an "index of practice"; thus, the governments can identify the level of their political stabilities and link it with their tourism performance.

\section{CONCLUSION}

Very limited attention has hitherto been paid to political-specific issues that may significantly guide the successful formation of destination image. Therefore, on top of the classical antecedents of destination image, we incorporate particular factors linked with the political (in)stability of the destination. The research on this issue is so far quite rare, especially from the viewpoint of tourists. This study examines the interrelationships between destination attributes, political (in)stability, destination image, tourist satisfaction, and intention to recommend. The findings show the predictive power of political (in)stability in tourist behavior models. The results suggest that political stability is more important than destination image in predicting both tourist satisfaction and the intention to recommend. Our contribution to the destination image literature is clear. The results highlight the relative significance of various attributes and political (in)stability in explaining the intention to recommend. The study shows the predictive power of political (in)stability and destination image in tourist behavior models. The current study enhances current theorizations by examining the merits of political (in)stability in models of tourists' intention to recommend.

\section{ORCID ID}

Riyad Eid (iD) https://orcid.org/0000-0002-5900-2225

\section{REFERENCES}

Agag, G., \& El-Masry, A. A. (2016a). Understanding consumer intention to participate in online travel community and effects on consumer intention to purchase travel online and WOM: An integration of innovation diffusion theory and TAM with trust. Computers in Human Behavior, 60(4), 97-111. 
Agag, G. M., \& El-Masry, A. A. (2016b). Understanding the determinants of hotel booking intentions and moderating role of habit. International Journal of Hospitality Management, 54(1), 52-67.

Agag, G. M., \& El-Masry, A. A. (2017). Why do consumers trust online travel websites? Drivers and outcomes of consumer trust toward online travel websites. Journal of Travel Research, 56, 347-369.

Alegre, J., \& Garau, J. (2010). Tourist satisfaction and dissatisfaction. Annals of Tourism Research, 37, 52-73.

Altinay, L., \& Bowen, D. (2006). Politics and tourism interface: the case of Cyprus. Annals of Tourism Research, 33, 939-956.

Alvarez, M. D., \& Campo, S. (2014). The influence of political conflicts on country image and intention to visit: A study of Israel's image. Tourism Management, 40, 70-78.

Anderson, J.C. and Gerbing, D.W. (1988). Structural equation modeling in practice: A review and recommended two-step approach. Psychological Bulletin, 103(3), p.411.

Armenski, T., Dwyer, L., \& Pavluković, V. (2018). Destination competitiveness: Public and private sector tourism management in Serbia. Journal of Travel Research, 57, 384-398.

Assaker, G., \& Hallak, R. (2013). Moderating effects of tourists' novelty-seeking tendencies on destination image, visitor satisfaction, and short- and long-term revisit intentions. Journal of Travel Research, 52, 600-613.

Bagozzi, R. P. (1994). Measurement in marketing research: Basic principles of questionnaire design. Principles of Marketing Research, 1, 1-49.

Bagozzi, R. P., \& Yi, Y. (1988). On the evaluation of structural equation models. Journal of the Academy of Marketing Science, 16, 74-94.

Baloglu, S., \& Brinberg, D. (1997). Affective images of tourism destinations. Journal of Travel Research, 35, 11-15.

Bigné, J. E., Andreu, L., \& Gnoth, J. (2005). The theme park experience: An analysis of pleasure, arousal and satisfaction. Tourism Management, 26, 833-844.

Blake, A., \& Sinclair, M. T. (2003). Tourism crisis management: US response to September 11. Annals of Tourism Research, 30, 813-832.

Buda, D. M. (2016). Tourism in conflict areas: Complex entanglements in Jordan. Journal of Travel Research, 55, 835-846.

Causevic, S., \& Lynch, P. (2013). Political (in)stability and its influence on tourism development. Tourism Management, 34, 45-157.

Cavlek, N. (2002). Tour operators and destination safety. Annals of Tourism Research, 29, 478-496.

Chen, C., \& Chen, F. (2010). Experience quality, perceived value, satisfaction and behavioral intentions for heritage tourists. Tourism Management, 31, 29-35.

Chen, C. F., \& Phou, S. (2013). A closer look at destination: Image, personality, relationship and loyalty. Tourism Management, 36, 269-278.

Chen, C. F., \& Tsai, D. (2007). How destination image and evaluative factors affect behavioral intentions? Tourism Management, 28, 1115-1122.

Chi, C. G. Q., \& Qu, H. (2008). Examining the structural relationships of destination image, tourist satisfaction and destination loyalty: An integrated approach. Tourism Management, 29, 624-636.

Cohen, S. (1988). Perceived stress in a probability sample of the United States. 
Crompton, J. L. (1979). An assessment of the image of Mexico as a vacation destination and the influence of geographical location upon the image. Journal of Travel Research, 18, 18-23.

Crouch, G. I. (2011). Destination competitiveness: An analysis of determinant attributes. Journal of Travel Research, 50, 27-45.

Del Bosque, I. R., \& San Martín, H. (2008). Tourist satisfaction a cognitive-affective model. Annals of Tourism Research, 35, 551-573.

Dolnicar, S., Coltman, T., \& Sharma, R. (2015). Do satisfied tourists really intend to come back? Three concerns with empirical studies linking satisfaction to behavioral intentions. Journal of Travel Research, 54, 152-178.

Eid, R. (2015). Integrating Muslim customer perceived value, satisfaction, loyalty and retention in the tourism industry: An empirical study. International Journal of Tourism Research, 17, 249-260.

Eid, R., \& Elbanna, S. (2018). A triangulation study to assess the perceived city image in the Arab Middle East context: The case of Al-Ain in the UAE. Tourism Planning \& Development, 15, 118-133.

Eid, R., \& El-Gohary, H. (2015). Muslim tourist perceived value in the hospitality and tourism industry. Journal of Travel Research, 54, 774-787.

Eilat, Y., \& Einav, L. (2004). Determinants of international tourism: a three-dimensional panel data analysis. Applied Economics, 36, 1315-1327.

Ekinci, Y., Dawes, P., \& Massey, G. (2008). An extended model of the antecedents and consequences of consumer satisfaction for hospitality services. European Journal of Marketing, 42, 35-68.

Elliot, S., Papadopoulos, N., \& Kim, S. S. (2011). An integrative model of place image: Exploring relationships between destination, product, and country images. Journal of Travel Research, 50, 520-534.

Eusébio, C., \& Vieira, A. L. (2013). Destination attributes' evaluation, satisfaction and behavioural intentions: A structural modelling approach. International Journal of Tourism Research, 15, 66-80.

Fakeye, P. C., \& Crompton, J. L. (1991). Image differences between prospective, first time, and repeat visitors to the Lower Rio Grande Valley. Journal of Travel Research, 30, 10-16.

Farber, M. E., \& Hall, T. E. (2007). Emotion and environment: Visitors' extraordinary experiences along the Dalton Highway in Alaska. Journal of Leisure Research, 39, 248-270.

Faullant, R., Matzler, K., \& Mooradian, T. A. (2011). Personality, basic emotions, and satisfaction: Primary emotions in the mountaineering experience. Tourism Management, $32,1423-1430$.

Fornell, C., \& Larcker, D. (1981). Evaluating structural equation models with unobservable variables and measurement error. Journal of Marketing Research, 18, 39-50.

Fu, H., Ye, B. H., \& Xiang, J. (2016). Reality TV, audience travel intentions, and destination image. Tourism Management, 55, 37-48.

Fuchs, G., \& Reichel, A. (2006). Tourist destination risk perception: The case of Israel. Journal of Hospitality and Leisure Marketing, 14, 81-106.

Fuchs, G., Uriely, N., Reichel, A., \& Maoz, D. (2013). Vacationing in a terror-stricken destination: Tourists' risk perceptions and rationalizations. Journal of Travel Research, 52, 182-191. 
Gallarza, M. G., \& Saura, I. G. (2006). Value dimensions, perceived value, satisfaction and loyalty: An investigation of university students' travel behavior. Tourism Management, 27, 437-452.

Gannon, M. J., Baxter, I. W., Collinson, E., Curran, R., Farrington, T., Glasgow, S., . . . Maxwell-Stuart, R. (2017). Travelling for Umrah: Destination attributes, destination image, and post-travel intentions. Service Industries Journal, 37, 448-465.

Gartner, W. C. (1993). Image formation process. Journal of Travel \& Tourism Marketing, 2, 191-216.

Goeldner, C. R., \& Ritchie, J. B. (2007). Tourism principles, practices, philosophies. Hoboken, NJ: Wiley.

Goldsmith, R., \& Flynn, R. L. (1992). Identifying innovators in consumer product markets. European Journal of Marketing, 26, 42-55.

Grappi, S., \& Montanari, F. (2011). The role of social identification and hedonism in affecting tourist re-patronizing behaviors: The case of an Italian festival. Tourism Management, 32, 128-140.

Hair, J. F., Jr., Hult, G. T. M., Ringle, C., \& Sarstedt, M. (2016). A primer on partial least squares structural equation modeling (PLS-SEM). Thousand Oaks, CA: Sage.

Hall, C. M. (2010). Crisis events in tourism: Subjects of crisis in tourism. Current Issues in Tourism, 13, 401-417.

Hall, C. M., \& O’Sullivan, V. (1996). Tourism, political stability and violence. In A. Pizam \& Y. Mansfeld (Eds.), Tourism, crime and international security issues (pp. 105-121). New York, NY: Wiley.

Hall, C. M., Timothy, D. J., \& Duval, D. T. (2004). Security and tourism. Journal of Travel \& Tourism Marketing, 15, 1-18.

Hallmann, K., Zehrer, A., \& Müller, S. (2015). Perceived destination image: An image model for a winter sports destination and its effect on intention to revisit. Journal of Travel Research, 54, 94-106.

Henderson, J. C. (2000). War as a tourist attraction: The case of Vietnam. International Journal of Tourism Research, 2, 269-281.

Hyun, M. Y., \& O'Keefe, R. M. (2012). Virtual destination image: Testing a telepresence model. Journal of Business Research, 65, 29-35.

Jeong, C., Holland, S., Jun, S. H., \& Gibson, H. (2012). Enhancing destination image through travel website information. International Journal of Tourism Research, 14, 16-27.

Katircioglu, S. (2009). Revisiting the tourism-led-growth hypothesis for Turkey using the bounds test and Johansen approach for cointegration. Tourism Management, 30, 17-20.

Kim, J. (2014). The antecedents of memorable tourism experiences: The development of a scale to measure the destination attributes associated with memorable experiences. Tourism Management, 44, 34-45.

Ladhari, R. (2007). The movie experience: A revised approach to determinants of satisfaction. Journal of Business Research, 60, 454-462.

Lee, B., Lee, C. K., \& Lee, J. (2014). Dynamic nature of destination image and influence of tourist overall satisfaction on image modification. Journal of Travel Research, 53, 239-251.

Lee, H., \& Hsu, F. (2013). Examining how attending motivation and satisfaction affects the loyalty for attendees at aboriginal festivals. International Journal of Tourism research, 15, 18-34. 
Lin, I. Y., \& Mattila, A. S. (2010). Restaurant servicescape, service encounter, and perceived congruency on customers' emotions and satisfaction. Journal of Hospitality Marketing \& Management, 19, 819-841.

Lindell, M.K. and Whitney, D.J. (2001). Accounting for common method variance in cross-sectional research designs. Journal of Applied Psychology, 86(1), p.114.

Loi, L. T. I., So, A. S. I., Lo, I. S., \& Fong, L. H. N. (2017). Does the quality of tourist shuttles influence revisit intention through destination image and satisfaction? The case of Macao. Journal of Hospitality and Tourism Management, 32, 115-123.

Matthews, H. G. (1974). International tourism and political science research. Annals of Tourism Research, 2, 195-203.

Matthews, H. G., \& Richter, L. K. (1991). Political science and tourism. Annals of Tourism Research, 18, 120-135.

Murphy, P., Pritchard, M. P., \& Smith, B. (2000). The destination product and its impact on traveller perceptions. Tourism Management, 21, 43-52.

Nam, J., Ekinci, Y., \& Whyatt, G. (2011). Brand equity, brand loyalty and consumer satisfaction. Annals of Tourism Research, 38, 1009-1030.

Neumayer, E. (2004). The impact of political violence on tourism: Dynamic crossnational estimation. Journal of Conflict Resolution, 48, 259-281.

Oliver, R. L. (1997). Satisfaction: A behavioral perspective on the consumer. New York, NY: McGraw-Hill.

Podsakoff, P. M. \& Organ, D. W. (1986). Self-reports in organizational research: Problems and prospects. Journal of Management, 12, 531-544.

Prayag, G., Hosany, S., Muskat, B., \& Del Chiappa, G. (2017). Understanding the relationships between tourists' emotional experiences, perceived overall image, satisfaction, and intention to recommend. Journal of Travel Research, 56, 41-54.

Richter, L. K. (1983). Tourism politics and political science. A case of not so benign neglect. Annals of Tourism Research, 10, 313-335.

Richter, L. K., \& Waugh, W. (1986). Terrorism and tourism as logical companions. Tourism Management, 7, 230-238.

Roehl, W. S., \& Fesenmaier, D. R. (1992). Risk perceptions and pleasure travel: An exploratory analysis. Journal of Travel Research, 30, 17-26.

Roldán, J.L. and Sánchez-Franco, M.J. (2012). Variance-based structural equation modeling: guidelines for using partial least squares in information systems research. In Research methodologies, innovations and philosophies in software systems engineering and information systems (pp. 193-221). IGI Global.

Saha, S., \& Yap, G. (2014). The moderation effects of political instability and terrorism on tourism development: A cross-country panel analysis. Journal of Travel Research, $53,509-521$.

Sanchez, J., Callarisa, J., Rodriguez, M., \& Moliner, M. A. (2006). Perceived value of the purchase of a tourism product. Tourism Management, 27, 394-409.

Sannassee, R. V., \& Seetanah, B. (2015). The influence of trust on repeat tourism: The Mauritian case study. Journal of Hospitality Marketing \& Management, 24, 770-789.

Saunders, M., Lewis, P., \& Thornhill, A. (2007). Research methods for business students (4th ed.). London. England: Prentice Hall.

Seetanah, B., Teeroovengadum, V., \& Nunkoo, R. S. (2018). Destination satisfaction and revisit intention of tourists: Does the quality of airport services matter? Journal of Hospitality \& Tourism Research. Advance online publication. doi:1096348018798446 
Sönmez, S. F., \& Graefe, A. R. (1998). Influence of terrorism risk on foreign tourism decisions. Annals of Tourism Research, 25, 112-144.

Su, H., Cheng, K., \& Huang, H. (2011). Empirical study of destination loyalty and its antecedent: The perspective of place attachment. Service Industries Journal, 31, 2721-2739.

Sweeney, J. C., \& Soutar, G. (2001). Consumer perceived value: The Development of Multiple Item Scale. Journal of Retailing, 77, 203-220.

Teye, V. B. (1988). Coups d'etat and African tourism: A study of Ghana. Annals of Tourism Research, 15, 329-356.

United Nations World Tourism Organization. (2015). Poverty alleviation through tourism: A compilation of good practices. Madrid, Spain: Author.

United Nations World Tourism Organization. (2017). Tourism Highlights: 2017 Edition. Retrieved from http://www2.unwto.org/publication/unwto-tourism-highlights-2017

Venkatesh, V., \& Brown, S. A. (2001). A longitudinal investigation of personal computers in homes: Adoption determinants and emerging challenges. MIS Quarterly, 25(1), 71-102.

Walmsley, D. J., \& Young, M. (1998). Evaluative images and tourism: The use of personal constructs to describe the structure of destination images. Journal of Travel Research, 36, 65-69.

Walters, G., Wallin, A., \& Hartley, N. (2018). The threat of terrorism and tourist choice behavior. Journal of Travel Research. Advance online publication. doi: $10.1177 / 0047287518755503$

Westbrook, R. A., \& Oliver, R. L. (1991). The dimensionality of consumption emotion patterns and consumer satisfaction. Journal of Consumer Research, 18, 84-91.

Williams, P. W., Stewart, K., \& Larsen, D. (2012). Toward an agenda of high-priority tourism research. Journal of Travel Research, 51, 3-11.

Yoon, Y., \& Uysal, M. (2005). An examination of the effects of motivation and satisfaction on destination loyalty: A structural model. Tourism Management, 26, 45-56.

Zhang, H., Fu, X., Cai, L., \& Lu, L. (2014). Destination image and tourist loyalty: A meta-analysis. Tourism Management, 40, 213-223.

\section{Submitted December 8, 2017 \\ Accepted January 12, 2019 \\ Refereed Anonymously}

Riyad Eid is a professor of Marketing at the United Arab Emirates University, UAE. His research Interests include Internet marketing, Customer Relationship Marketing (CRM), service quality, customer value and Islamic Tourism Marketing. Riyad.aly@uaeu.ac.ae

Yasser Ahmed El-Kassrawy is an associate professor of business Administration at Tanta University, UAE. His research Interests include MIS, research methods and Marketing.

Gomaa Agag is a senior lecturer in marketing, Nottingham Business School, UK and Sadat City University, Egypt. His research interests include Electronic Marketing, Electronic Commerce, Internet Marketing and Small Business Enterprises and tourism Marketing. 